\title{
DEVELOPMENT OF AUTOMATION FOR FOUNDATION ENGINEERING - CASE PILING MACHINE AND THE WORKING PROCESS OF DRIVEN PILING
}

\author{
Rauno Heikkilä \\ University of Oulu, Oulu, Finland \\ rauno.heikkila@oulu.fi \\ Teemu Kivimäki \\ University of Oulu, Espoo, Finland \\ teemu.kivimaki@oulu.fi \\ Katja Puolitaival \\ University of Oulu, Espoo, Finland \\ katja.puolitaival@oulu.fi
}

\begin{abstract}
This paper introduces and discusses the aims and first results of a large active research project in Finland. One of the aims of the project is to develop an automated total process for driven piling machine. Several tests have been made and some of the results are briefly discussed. The paper focuses mainly on the latent economic and environmental benefits of current concrete driven piling process, which remain to be attained through utilization of more automated methods and systems. Automation was found to have remarkable latent economic benefits in the development of concrete driven piling. The evaluations and statistical calculations showed up to $40 \%$ of the direct costs could be saved by utilizing advanced techniques and methods in driven piling. Time savings, energy savings and environmental benefits were also remarkable. Additional direct as well as wider indirect benefits are also presented.
\end{abstract}

KEYWORDS: 3D, automation of driven piling, sustainability

\section{INTRODUCTION}

\subsection{Background}

The current global market potential for the application of new technology for pile driving is judged to be exceptionally significant. Automation is assessed as being particularly wellsuited to the so-called continuous piling method (Heikkilä 2007, Juvankoski et al. 2007). To date, the pile work in the overall functional process makes very little use of information and automation technology opportunities. With the exception of few experiments or researches (Seward 1997), 3D positioning methods have not yet been integrated with the control of the pile-driving machine. Currently, control of the piles and work machine at the work site is based on positioning measurements carried out with case-specific methods by the measuring group, in which the input data is obtained from the planning documents. A helper guides and assists the operator's work. The machine's present control system gives few opportunities for 
managed control and optimization of the piling. Piling is terminated when the settlement observed in the final impact count measurement is lower than the so-called final impact count settlement set by the geotechnician. A small fraction of the implementation data of the pile work is manually documented on paper. The geotechnical bearing capacity achieved with the pile is only evaluated in exceptional circumstances with a separately ordered PDA (Pile Dynamic Load) Test. The PDA is on of the most widely used system for dynamic load testing and pile driving monitoring.

In Sweden, an accepted practice for foundation engineering is that the maximum allowed load for the pile can be increased by over $50 \%$ of its maximum when the pile bearing capacity is known-PDA measurements are carried out to produce this information. If during the piling stage the geotechnical bearing capacity achieved with the pile could be measured with the work machine's control system using new automation technology, a significant economic benefit could be attained with this alone. It has been estimated that the pile work costs could thus be reduced by as much as 30\% (Heikkilä 2007). In addition to this, another estimated significant benefit was that pile-driving work utilizing such a measurement and control system could be stopped immediately once the required bearing capacity was achieved. Also in this case, the benefits attained would be significant. Optimization of the foundation work based on implementation data observed in real time can be done, if necessary, at a continuous pace with the work progress. (Heikkilä 2007).

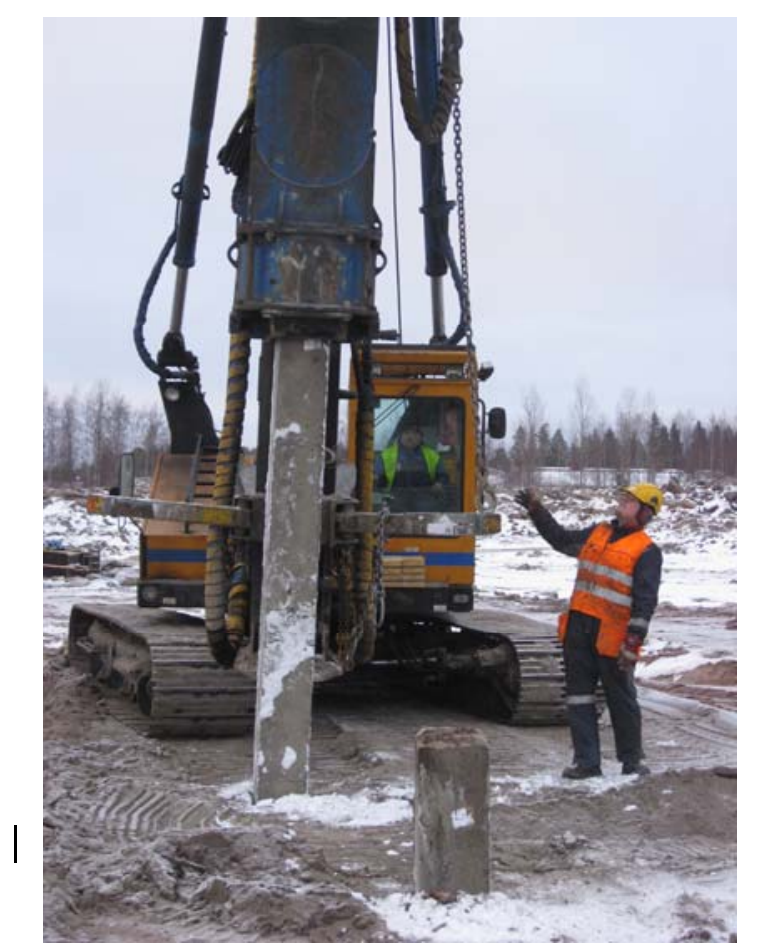

Figure 1. Traditional Piling Process (University of Oulu):

- Control of machine and piles is based on dimensioning measurements, data is taken from $2 D$ drawings

- No 3D positioning systems have been integrated into piling machine

- Operator is assisted by helper

- Piling terminates after pile descends less than the target value set by geotechnician.

- Only small part of the information is gathered and documented to paper records

- Final bearing capacity is measured only in the most demanding cases, using special PDA measurement technique.

In addition to the earlier results, the study can leverage the results of several other research and development projects in the same way as with new technologies arriving on the market. For example, the Luja Group in Finland has done significant development work on the JOPI technology in recent years (JOPI is a Finnish acronym, which stands for: pile of exactly the right length), including the continuous piling method (standard-dimensioned pile, factory automation, circular saw mounted on a pile-driving machine) and the "quick-coupling parts" of a reinforced concrete pile connected to them (Emeca Oy). With this method, waste of pile 
materials can be almost completely eliminated. Furthermore, Junttan Oy has developed realtime measuring systems for driving energy and pile penetration. However, a kinematic and inverse kinematic 3D overall system for the machine has not yet been developed. The development and expansion of this solution for the utilization of auxiliary equipment and continuous 3D input data and control models, and for the calculation and management of geotechnical limit values offer very extensive potential development opportunities of new characteristics, as well as business and export opportunities (integrated overall solutions, subsystems). With the overall management, the most competitive pile-driving process can be created for the global markets. (Heikkilä 2007, Juvankoski et al. 2007).

\subsection{Objectives}

The main objective of the research project "Development of Automation for the Foundation Engineering of Building and Infra Construction - POHVA-II" was to develop a 3D functional process for foundation engineering utilizing automation needed in the sub-areas of pile driving, mass and column stabilization, and the sub-technologies and methods needed for these, in which the efficiency and quality of the measuring, planning, implementation and realization measuring process can be improved. The partial objectives enabling the achievement of the main objective were:

- completion of the necessary specific scientific research and development tasks for the development of the overall functional process,

- $\quad$ modeling of the overall functional process for implementation of full-scale test projects, and

- implementation of the experimental automation overall functional process in actual construction projects.

The target automation process in the application area of pile driving includes several different parts and phases:

- $\quad$ manufacturing automation of the pile and its steel parts;

- $\quad$ measurement and planning of the 3D soil model and the geotechnical product model;

- $\quad 3 D$ piling plan (i.e. the machine control model, geometry, target bearing capacity), its planning methods and tools, and data transfer to the work machine control system;

- $\quad$ automated 3D control of the work machine (functional co-ordinates, positioning system, sensor system, overall kinematics, control of actuators), remote control, possible use of pile magazines;

- $\quad$ continuous piling installation procedure;

- $\quad$ real-time measurement and calculation of the geotechnical bearing capacity relative to target;

- $\quad$ pile cutting at the level according to the plan with a numerically-controlled saw on the work machine;

- $\quad$ automated real-time monitoring and management of environment- and constructionborne vibrations and other environmental changes;

- $\quad$ and automated documentation of the implementation process. 


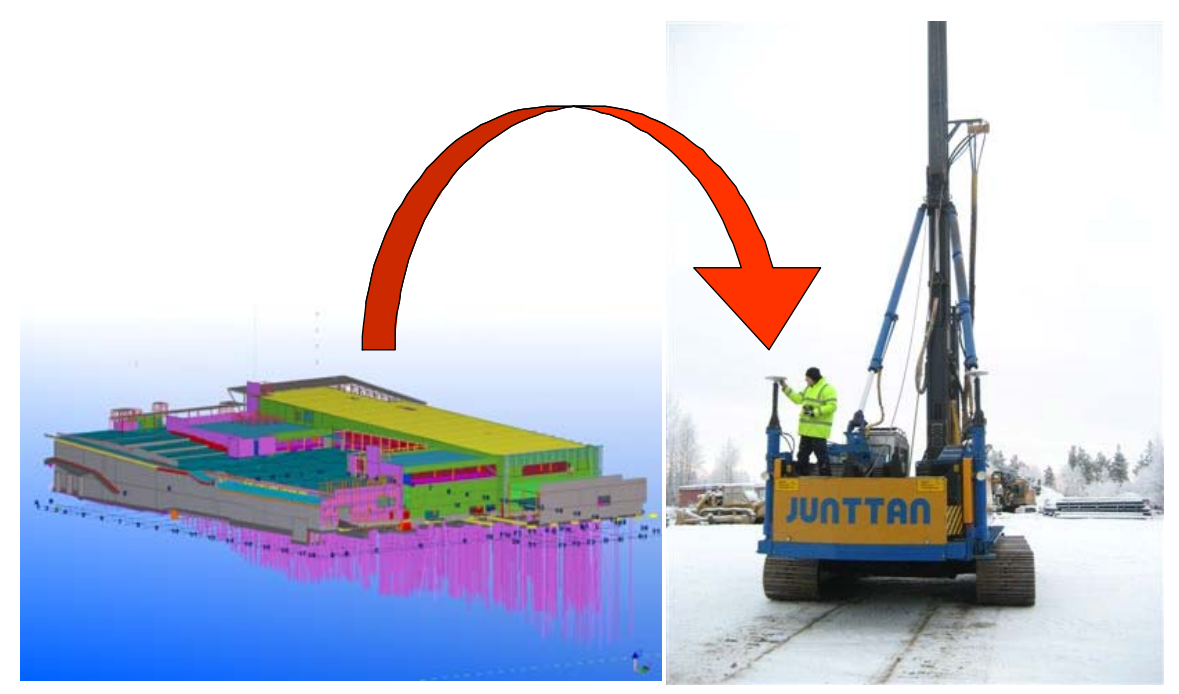

Fig. 2. The development of an automated process for driven piling in the POHVA-II research: the design data for machine control model (left), the first $3 D$ positioning tests (right).

This paper focuses on evaluating and reporting the economic potential of this type of automation for the concrete driven piling process.

\section{METHOD}

First, the economic potential of the automation of driven piling process was evaluated using an Excel sheet developed by the University of Oulu. The evaluation was made with collaboration of the main industrial companies (a pile manufacturer, a piling contractor, and research organizations) evolved into the concrete driven piling process in Finland. The most effective different work phases (out of a total of 35 phases) were identified and included in the evaluation of the direct identified costs for piling contractor, general contractor and owner of the process. The initial data (key input factors of different pile construction sites) used were: total length of piles, average length of piles, distance between the site and the pile factory, number of piling machines used, average daily labour productivity, total number of pile points, duration of piling work, and evaluated waste percentage of piles. Present unit cost information was gathered from the same companies.

Second, the same potentials were evaluated and compared statistically based on site case studies. This study concentrated on the waste, environmental impacts, and effects to the project control. 
Table 1. Initial data from three construction sites called Pajunkissa (small size), Pomeranssi (mid-size) and Iitti (big size) used for the statistical calculations.

\begin{tabular}{lllrr}
\hline Construction sites & measurement & Pajunkissa & Pomeranssi & litti \\
& unit & Kuopio & Helsinki & \\
\hline Number of pile points & amount & 129 & 1727 & 3000 \\
Pile depth & $\mathrm{m}$ & $3-8$ & $6-17$ & $28-33$ \\
Waste & $\%$ & 24.3 & 18 & 15 \\
Waste & $\mathrm{m}$ & 193 & 3222 & 400 \\
Labour productivity & m/day & 100 & 260 & 400 \\
Time length & day & 8 & 70 & 77 \\
Number of machines & amount & 1 & 1 & 3 \\
Distance to pile factory & $\mathrm{km}$ & 188 & 70 & 65 \\
Distance to crushing plant & $\mathrm{km}$ & 23 & 20 & 50 \\
\hline
\end{tabular}

Financial, time, and quality waste were studied in traditional and automated column stabilization and pile driving processes. The prices of the traditional and automated processes were calculated using the @Risk program developed by Palisade Corporation (http://www.palisade.com/risk/default.asp). Environmental impacts where calculated using Life Cycle Assessments (LCA). Impacts of the automated process for project control were evaluated using a questionnaire. The aim was to recognize the problems and development probabilities of project control in foundation engineering.

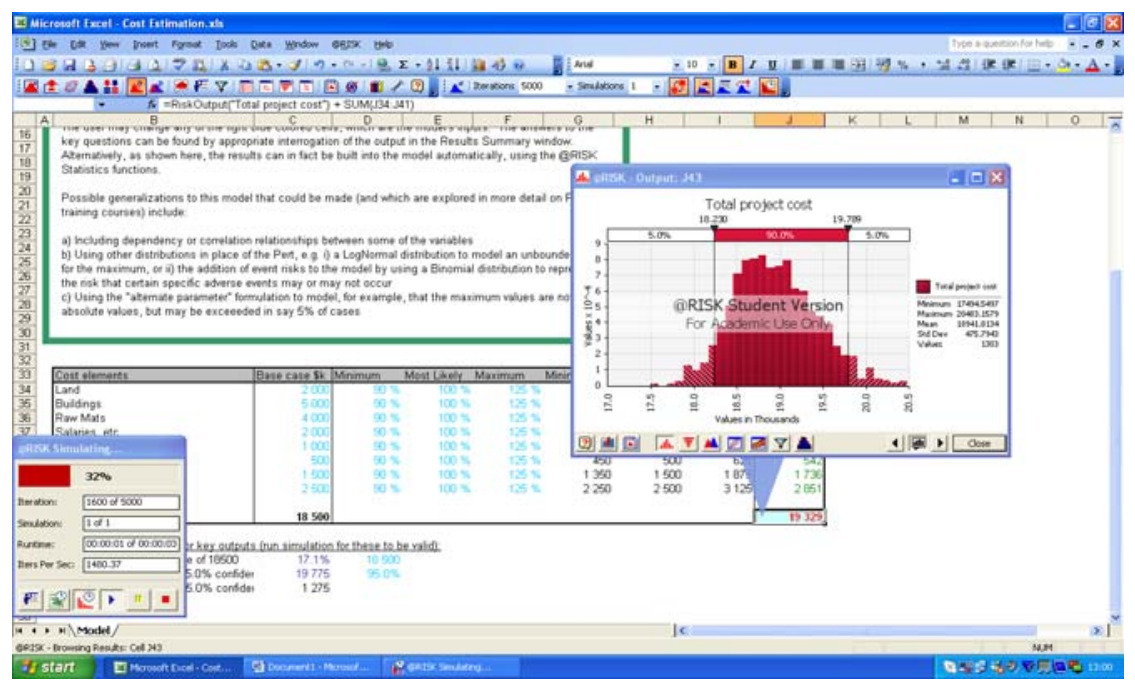

Fig. 2. The economic calculations were made using @Risk program and Monte Carlo simulation.

\section{RESULTS}

Based on the direct costs evaluation performed in Excel, nearly $40 \%$ of the costs of concrete driven piling could be saved using the determined type of automation in piling process (Table 2). In Finland, this would mean about 33 million eur annual saving in piling works. The key factor enabling the savings is the possibility to avoid waste pile meters (number of meters of pile driving that are not needed) and the utilization of measured geotechnical capacity of driven piles. 
Table 2. An evaluation of the economic potential of driven piling (University of Oulu).

\begin{tabular}{lcrrr}
\hline piling costs & unit & traditional piling & automated piling & saving \\
\hline driven meter & [eur/m] & 44.50 & 27.08 & 17.42 \\
construction site & [eur] & $222,478.00$ & $135,382.00$ & $87,096.00$ \\
Total in Finland & [eur/year] & $66,743,325.00$ & $33,710,168.00$ & $33,033,157.00$ \\
\hline
\end{tabular}

In the statistical calculations using the @Risk program and Monte Carlo simulation, the automated driven piling process was cheaper in all different construction sites and calculated situations. In driven piling process, the automated process was $36 \%$ cheaper than traditional process for a small site, $30 \%$ cheaper for a mid-size site and $22 \%$ cheaper for a big site. Every site had different initial data. The biggest influence for the whole process was the pile consumption and pile price per meter. Continuous driven piling method (JOPI) and real-time carrying capacity measurement reduced pile consumption in automated process. The use of continuous piling method saves remarkable material and financial waste.

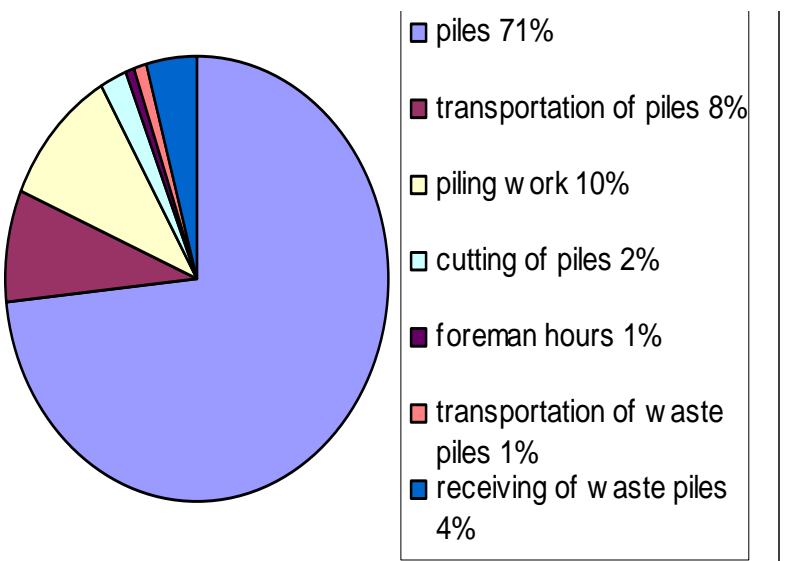

Figure. 3. The proportional costs of traditional driven piling (costs under 1\% not shown).
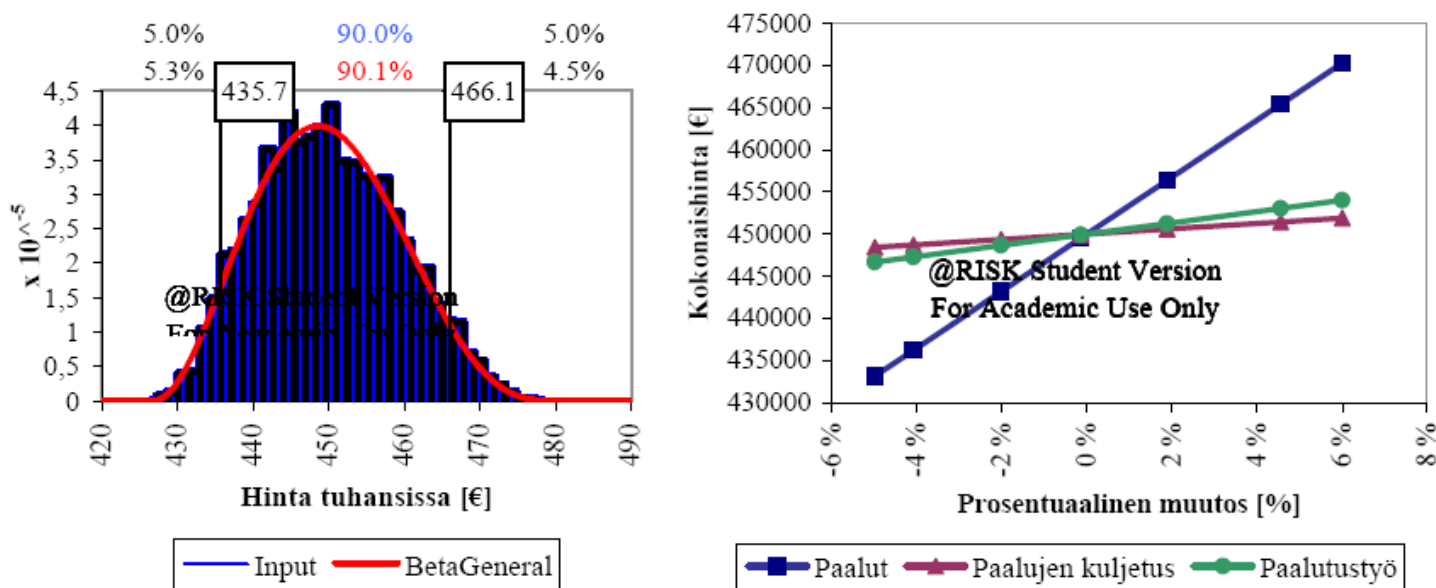

Figure 4. Evaluation of the benefits by @Risk program ("hinta tuhansissa" = costs in thousands euros, "prosentuaalinen muutos" = pergentage change, "kokonaishinta" = total costs, "paalut" = piles, "paalujen kuljetus' = transportation of piles, "paalutustyo" = piling work). 


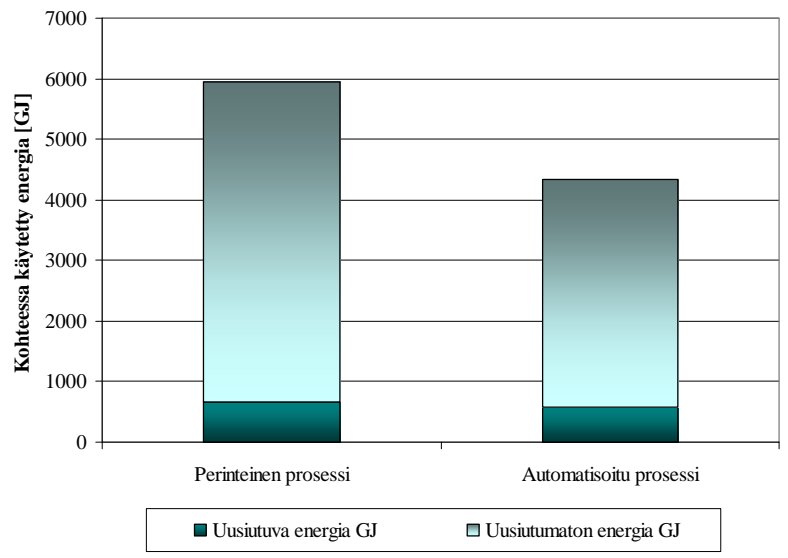

Figure 5. Evaluation of the energy savings by @Risk program (traditional process - left, automated process - righ, "kohteessa kaytetty energia" = the energy used at the site, "uusiutuva" means renewable energy source, "uusiutumaton" nonrenewable energy source).

In the large-size driven piling site, energy consumption was reduced by $7100 \mathrm{GJ}$ and carbon dioxide release by 821 tons. In all, 99 single family houses could be heated by this saved energy for one-year period in Finland. The saved carbon dioxide equals the release from 63 commercial flights from Oulu to Helsinki (about a one-hour flight) assuming the aircrafts are full of passengers. In the middle-size driven piling site energy consumption was reduced by $1600 \mathrm{GJ}$ and carbon dioxide release by 182 tons. The automation process remarkably reduces the environmental impacts. The time saving in Pajunkissa site was about 2 work days, in Pomeranssi site about 10 work days and in Iitti site about 3 work days. An important part of project control is to be aware of risks and adapt to site changes. Some risks can be removed or reduced using the automation process. This is a direct advantage for project control.

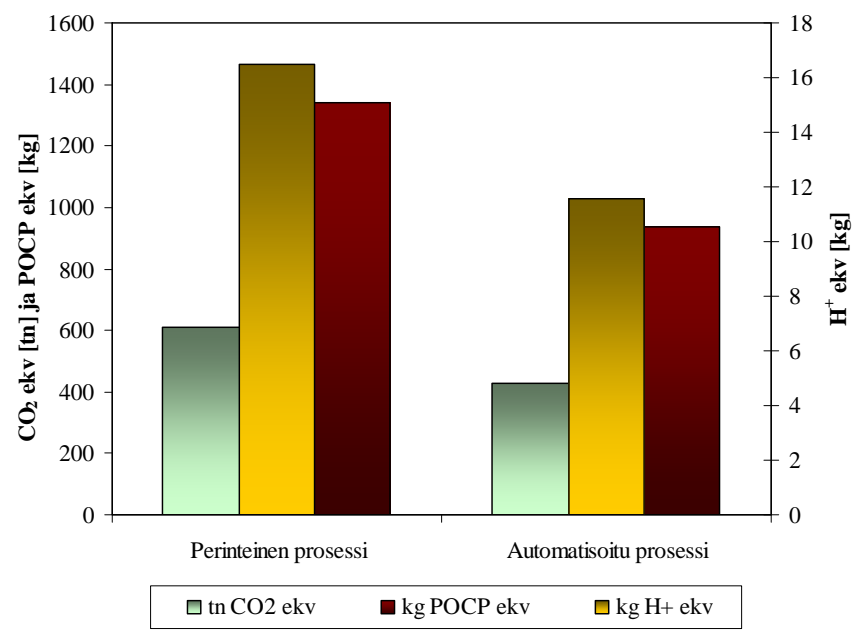

Figure 6. Evaluation of the environmental effects by @Risk program (traditional process - left, automated process - right). 


\section{CONCLUSIONS}

Automation has remarkable latent economical benefits in the development of concrete driven piling. Both the evaluation and statistical calculations showed up to $40 \%$ of the direct costs can be saved by utilizing advanced techniques and methods in driven piling. Also the time savings, energy savings and environmental benefits were remarkable. The key factor enabling the savings is the possibility to avoid waste pile meters and the utilization of measured geotechnical capacity of driven piles. Continuous driven piling method and real-time carrying capacity measurement reduced pile consumption in the automated process. The use of continuous piling method saves remarkably material and financial waste. Significant other direct as well as wider indirect benefits were identified in the research. Thus, the development of more automated process for driven piling is one of the very potential means to promote remarkably sustainable and green development in foundation engineering.

\section{REFERENCES}

Heikkilä, R. (2007) Tietoverkottunut, 3D-mallinnukseen ja -mittauksiin perustuva pohjavahvistusautomaatio (POHVA). 3D-maaperämalli syvästabilointiin ja paalutukseen sekä pohjasuhdetiedon hallinnan riskit. Oulun yliopiston Rakentamisteknologian tutkimusryhmän tutkimusraportti. Oulu, Oulun yliopisto, Rakentamisteknologian tutkimusryhmä. Loppuraportti. 19 s. [in Finnish only]

Juvankoski, M. \& Valasti, P. \& Korkiala-Tanttu, L. (2007) 3D-maaperämalli syvästabilointiin seka pohjasuhdetiedon hallinnan riskit. Espoo, VTT, tutkimusraportti n:o VTT-R-10654-07, 119 s. [in Finnish only]

Kauppi, M. \& Pätsi, K. \& Heikkilä, R. (2008) Informaatio- ja automaatioteknologian kehittäminen maa- ja talonrakentamisen pohjarakentamiseen (POHVA II), Pilaristabiloinnin konetyön tehokkuuden parantaminen - työntutkimusraportti. Oulu, Oulun yliopisto, Rakentamisteknologian tutkimusryhmä. Väliraportti. 19 s. [in Finnish only]

Paitsola, J. \& Heikkilä, R. (2008) Lyöntipaalutuksen konetyön tehokkuuden parantaminen työntutkimusraportti. Informaatio- ja automaatioteknologian kehittäminen maa- ja talonrakentamisen pohjarakentamiseen (POHVA II). Oulu, Oulun yliopisto, Rakentamisteknologian tutkimusryhmä. Väliraportti. 32 s. [in Finnish only]

Seward, D. W., Scott J., Dixon R., Findlay J. \& Kinniburgh H (1997) the automation of piling rig positioning using satellite GPS. Automation in Construction 6 (1997), pp. 229-240.

Wang, L-C., Lin, Y-C. \& Lin, P. H. (2006) Dynamic mobile RFID-based supply chain control and management system in construction, Advanced Engineering Informatics 21,pp. 377-390.

Wegelius-Lehtonen, T. \& Pahkala, S. (1998) Developing material delivery processes in cooperation: An application example of the construction industry, International Journal of Production Economics 56-57, pp. 689-698. 